DOI: https://doi.org/10.18485/philologia.2020.18.18.6

UDC: 821.111(415)-31.09 Baum S.

\title{
- COLLABORATIVE CO-EXISTENCE: HUMAN-ANIMAL BODIES AND NATURE IN SARA BAUME'S SPILL, SIMMER, FALTER, WITHER
}

\author{
ORSOLYA SZÜCS ${ }^{1}$ \\ Pázmány Péter Catholic University \\ Doctoral School of Literary Studies \\ Budapest, Hungary
}

Sara Bom je savremeni irski romanopisac i umetnik. Do sada je objavila dva romana i dokumentarnu zbirku "Artefakt" (2020). U ovom radu autor se bavi njenim romanom prvencom „Starac i jednooki" (2015). U ovom radu se sagledava kako Bomova koristi jezik da izrazi ono što određeni kognitivni psiholozi nazivaju kvalija (qualia): „stanje uma koje proističe iz osećanja kako je biti neko ili nešto ko/što doživljava određeno iskustvo". (Herman 2010: 173). Glavni junak romana je Rej, starac koji u životu nalazi izvesno olakšanje nakon što usvoji jednookog psa. Sa njim, Rej se upušta u pustolovinu u seoskim područjima Irske. To mu omogućuje da istražuje svoje 'simbiotske' polovine, 'simbiotsku' prirodu. Spisateljkin eskperimentalni pripovedački stil ne vrti se oko brzog i dramatičnog zapleta, već uvlači čitaoca u središte same radnje. Njen jezik besprekornih opisa omogućava čitaocu da se približi protagonisti koji proživljava razna iskustva i sagledava pejzaže i životinjski svet, što dovodi do buđenja dubokih osećanja u čoveku. Rad takođe ispituje inovativne načine kojima se može preispitati povezanost životinja i ljudi tako što bi se stvorila nova i drugačija koegzistencija u našem antropocentričnom dobu. Bomova zalazi u ključne etičke teme i postavlja važna pitanja o mogućnosti skladnijeg suživota ljudi i prirode.

Ključne reči: savremena irska fantastika, telo, životinje, pejzaž, jezik, antropocentričan, narativ.

1 Kontakt podaci (Email): orsolya.szucs@yahoo.com 


\section{INTRODUCTION}

There is an important paradox that is noticeable in our contemporary societies. In one way, people are urged to have a heightened focus on their appearance, and as such, on their bodies. Tattoos, body-modifications of all sorts, training programs, healthobsessions all direct the focus on the physical. At the same time, we also live in a world of technology, cyborgs, virtual reality, which in turn distracts attention from the physical realm, transforming it into an afterthought. The focus shifts from the materiality of the body to drive the users into a universe of minds and thoughts expressed without the physical presence of the body. Irish essayist Sinead Gleeson expands this idea when she explains that in everyday life people tend to assume the material coordinates of the body, its weight, the working of the organs as a given:

Unless it's involved in pleasure or pain, we pay this moving mass of vessel, blood and bone no mind. The lungs inflate, muscles contract, and there is no reason to assume they won't keep on doing so. [...] The body - its presence, its weight - is both an unignorable entity and routinely taken for granted. (Gleeson 2019: 1)

There is one consistent occurrence, though, that has been a moment of bodyawareness since the existence of humanity i.e. illnesses. One usually becomes more body-conscious and aware of one's own biological ephemerality in case of sickness, old age, or experiences at the limit, when the finite capacities of matter suddenly become obvious. Psychologist Bessel Van Der Kolk states that even when experience, especially a traumatic one is treated as forgotten, the body works as a precise mnemonic device "the physical effect on the organs go unabated until they demand notice when they are expressed as illness [...] the body continues to keep the score." (2015: 46) This happens in such a way that every emotion, every life event is carved into the body, and even when the mind tends to or wants to forget, our bodies are constant reminders. Cells store the memory of emotional pain, and the only way to rewire these memories is through reprogramming the body itself and the automatic reaction patterns that it created (Kolk 2015: 1-25).

Can reading, reading about our own and others' experiences and coping strategies be a type of therapy of similar rewiring? It can be suggested that reading about other human beings going through time and space can challenge the way we think of ourselves and our own bodies.

One of the fields in human culture that has been preoccupied with the body is literature. Novels record what it is like to lead a life in a human body. Writing is tied to the body and what the body experiences, and through the process of reading, one is forced into the experience itself. Controlling a narrative through writing also means controlling bodies and minds that exist through the dimension of narrative space and time. The Cambridge Companion to the Body in Literature (Hillman et al. 2015: 1) argues that "the body participates in crucial ways in thinking, feeling and the shaping of our personalities [...] being constitutive of what we call the self." However, bodies are hard to define or describe, as literary critic David Hillman sustains: "for the body, it is notoriously difficult to theorize or pin down, because it is mutable, in perpetual flux, 
different from day to day and resistant to conceptual definition." (2015: 1) And whereas there are no actual bodies in the written text, literature can change the way we think of our embodied life. As early as 1949, Gilbert Ryle stated that "novelists have always been satisfied to exhibit people's motives, thoughts, perturbations, and habits, by describing their doings, grimaces, gestures, and tones of voice." (1949: 301) This is why bodies, or more specifically, the mode and experiences of an embodied life, have long been the main focus of narrative writing. Sustaining Merleau-Ponty's assumption that every experience that a human being can have is essentially an embodied one - "rather than a mind and a body, man is a mind with a body" (Merleu-Ponty 2004: 67), the reading experience itself can be termed as a bodily one.

Analyzing the various representations of the body in literature has become a well-established approach in literary criticism. However, the body seems to be a rather under-theorized aspect of Irish fiction, although it carries relevance, particularly in contemporary Irish writing. According to critic Maeve E. Davey, the body is often the site through which "slippery concepts of national identity and ambivalence towards the prevailing conservative religious, cultural climate are represented." (2010: 12) James Joyce has constructed Ulysses by dedicating each chapter to an organ, referring directly or indirectly to it throughout the lines.

The experience of living in a body has started to gain a special focus in contemporary Irish non-fiction writing. Sinéad Gleeson, a contemporary Irish essayist, has recently published a collection entitled Constellations (2019) that centers on a very personal yet paradoxically universal theme of how it is to live through sickness, trauma, mother and womanhood. The fourteen essays in the book tell the history of the female body, as the writer herself argued: "it is about finding the parts you want to extract." (Dass 2019) She writes about pain, the body in pain, which is considered a universal and almost inexpressible experience, yet as Gleeson states, "pain is as unique as a fingerprint [...], I was interested in the inexpressibility of it" (Dass 2019). She forces the reader into the living body through a meticulous female voice, described by Anne Enright (2019: par. 4) as "coming from the blood and bone of her body's history."

On the terrain of Irish novel writing, there has been a noticeable boom of female writers in the past decades who challenge previous concepts regarding gender roles and national stereotypes in their work. Many of these novelists have created works that center around the body and its experiences. Sara Baume is a young, contemporary Irish writer and visual artist, who has so far published two novels and a non-fiction book entitled handiwork that appeared in March 2020. Thematically her works raise important questions about the limitations of art and the body, the struggles of early adulthood, Irish identity, womanhood, the decline of Irish rural living, and the relationship that humans have with their physical existence and through it with the natural world. She also implies a heightened need for a greater eco-awareness. The following essay examines how Baume uses language in her novel entitled Spill, Simmer, Falter, Wither (2015) to portray the landscape and the animal world, creating a bodytied, innovative narrative tone and style. 


\section{LANDSCAPE AND LANGUAGE}

Sara Baume's debut novel entitled Spill, Simmer, Falter, Wither was published in 2015 by a small Irish independent press, and since then, it has been translated into several languages. It can be termed experimental prose, or as the writer herself declared, a novel that seeks to "break the rules." (Crim 2016) The sense of genuine creativity or 'rule-breaking' is manifested through its narrative language and the mode of rendering seemingly traditional Irish topics like the broken family unit, religion, rural existence through a fascinatingly new perspective. The individual and the various ties that control its bodily and interconnected societal existence are in the central focus of the novel. Baume considers herself to be part of the Irish writers who dealt with rural tradition, like John McGahern or William Trevor (Crim 2016). However, although focusing on a rural setting, the style that she pursues is very different from that of McGahern's and Trevor's. In Baume's, prose the natural landscape is ripped from its geographical specificity and functions as an anthropomorphic projection of different states of human emotion. Nature has a paradoxically destructive yet also constructive power in her fictional world; it becomes a separate character of the plot. The narrative style conveys the immediate experience of nature with all its sounds and silences. The plot follows the uncanny co-existence of an old, solitary man and his pet. They are forced to run away from the village because the dog is falsely accused of biting a little child and faces the threat of being euthanized. Through a first-person utterance suspended in an eternal present of remembering, the protagonist retells and confesses his past life to his dog, while traveling across the rural Irish countryside. Ray, the protagonist, is very much an outsider, suspected to be suffering from childhood traumas. He was raised by a single father who did not show much affection towards his offspring. He is also an outcast from his community. He lives in a small seaside village, but never actually spoke to anyone. His social interactions were confined to his father and a neighbor, to whom he refers to as 'aunt'. He was also denied a formal education by his father, who simply degraded his son by lying that he was 'handicapped' and unable to attend school. From this perspective, Ray shares a lot in common with his nonhuman partner. The dog was suffering at a shelter house, physically damaged after a fight with a badger. Ray appears as a savior because no one wants to adopt him. They also become similar throughout the course of the novel, as the dog eases into Ray's loneliness. The dog becomes less feral through the care he receives while Ray adapts a similar observer, a sense-acute attitude towards the world as the dog. The dog is named One-Eye, referring to his physical handicap; he has lost one of his eyes in the respective badger fight. However, his other senses are very acute; he smells and hears other animals from a far distance. By spending time with this weird creature, Ray also learns a new mode of experience and starts to view the world animate and inanimate in a peculiar new detail, gaining a beauty that he was unable to find in human society.

Although language can act as a barrier in the process of evoking the bodily experience itself, Baume's style attempts to bring the reader as close as possible to qualia as defined by cognitive psychologists like David Herman (2010). Herman (2010) enumerates qualia (a term borrowed from Daniel Dennett) among the main capacities of every literary narrative. The term is described as "a state of the mind that arises from 
the feeling of what it's like to be someone or something having a given experience." (Herman 2010: 173) Baume's novel applies meticulous descriptions, using a surplus of adjectives that relate to all the senses so that it forces the reader into the experience. At the same time qualia has another layer in the text, the protagonist often gets carried away by his memories, he reveals moments from his childhood, but not through the eyes of that long gone child. Ray distances himself from the experience, he comments on them using qualia, trying to see himself as someone else. He makes himself the subject of his own understanding: "when I was a boy, I used to sit here in this window and watch children. [...] I didn't really believe I was of the same species as the children." (Baume 2015: 63-64) He also experiments with qualia whenever he tries to envision how living would feel in a dog's body: "What do you smell? Fox spray and honeysuckle, pine martens and stinkhorns, seven different kinds of sap?" (Baume 2015: 133) He is often amazed by his dog's complex olfactory ability: "You learn each new stopping spot detail by detail, by its symphony of smell, and never by its signpost." (Baume 2015: 140) The language of the narrative gives direct access to his thoughts capturing the vivid emotional, visual and sensory experiences. From the very beginning, the landscape acts as a crucial element in the character's life. Ray is staring into the distance and describes with minute detail both the view itself as well as the effects of it on his body:

At high tide, the sea rises to lap against the bird walk's wall, and gulls bob at beaklevel with the concrete. At low tide, the water falls back to expose a no man's land of stinking mud. It's at low tide that the wading birds come. Oystercatchers with their startled eyes [...] little egrets freshly laundered, whiter than white. (...) As I turn back you're still hustling amongst the greenery. (Baume 2015: 40)

The narrative focalization starts from a bird's eye view, and it slowly approximates itself towards the internal focalizer, the narrator. The human element is gradually introduced, being the endpoint of the description. Language functions here with almost total dramatic inertia, communication is being reduced to a minimum. When the characters do interact verbally, this is relayed through indirect speech and always as a moment that is recollected. This is partly due to the fact that the protagonist himself is an old, cantankerous, solitary man who has lost almost all social connections with the human world. Language is made into a living organism capable of producing an affective reading experience, one that can strongly apply to the senses. It is a language that makes the reader see, smell, and feel. At the same time, there is also a paradoxical mistrust in its expressive forces. Ray absolutely dreads human communication, yet puts a lot of trust in sensations that he values as authentic forms of expression: "the outer noises are important to me. It doesn't matter what form they take or how loud they are [...] I depend on them to gag my thoughts." (Baume 2015: 162)

The close connection to the natural world, animals, and the wordless beings is a narrative driving force in this novel; it tries to grasp the silence in a way too. It is a productive silence that seeks a more authentic mode of contemplation. Although transmitted through language, these descriptions of nature appeal directly to the senses and don't involve any communicatively informative purpose as a human verbal interaction would: 
The clifftop is studded with scabious, chamomile, campion. Ladybirds hug the grass stalks. Hoverflies tread the air. [...] Now there's silverweed, its under-leaves gilded like the scales of a white fleshed-fish. The track leaves down slope. The earth and furze give way to sea pinks and lichen."

(Baume 2015: 94)

They also function through a physical, bodily experience of living. Baume argues regarding her own writing: "I try to approach it with the sensibility of a filmmaker, to conceive of my fictional world as sound and vision as opposed to static letters of the alphabet arranged on a page to capture something." (2015: 2) This is why her narrative captures every modicum element of the setting or event that is described. The narrator carefully shows the different visual, auditory and olfactory aspects of close proximity objects as well as of those in the distance. Ray functions as a cameraman who silently transmits and verbalizes all the colors, scents and sounds. According to critic JeanMichel Rabaté (2015: 231), the different styles and modes of expression in novel writing can be attributed to different political, social, and economic structures surrounding the birth of the work. But the actual linguistic "product," the narrative itself is always about "the interaction of the human bodies" (Rabaté 2015: 231) inside and outside of the text. Novels explore the inevitable relationship between the body and the written word, having the capacity to sublimate or redirect bodily functions. Jean Luc-Nancy (2008:15) suggests that words are comprehensible through the body and are essentially linked to what the body as physical clothing experiences. At the same time, as he points out, the body as materiality is a complex "open space" and not a "filled space," it is a "place of existence," that is not settled, it is in a constant flow. (Nancy 2008: 15) Novels can have the power to carry their readers into an act of possession by allowing the entry into the experiences of characters, so that through reading our "emotional and cognitive repertoire expands." (Mahon 2017: 103) Baume's work can also be similarly described as a novel with style, with a language that forces the reader into the center of the experience. Everything is narrated through the eyes of the first-person narrator Ray who acts as an acute observes. He talks directly at his dog, addressing every sentence to his companion, often asking questions too, "Have I told you about my birthday?" (Baume 2015: 90) He reveals memories of his traumatic childhood, his loneliness and at the same time plays with the idea of imagining certain experiences from the perspective of the dog. His utterance is viscerally driven and it also functions as a re-living of all those emotions and sensations: "my father is the man you can smell all over the house [...] you'll smell his dead skin cells in the leather bind of never-opened books." (Baume 2015: 84) He also often examines his ageing body, commenting on it sarcastically: "even though my feet are uncommonly long and flat to balance the plundering mass of my limbs and pork of my gut." (Baume 2015: 84) The whole narrative is in a way a portrayal of the history of his body augmented with comments on how this ageing body finds ways to reconnect with the world around him. His bond with the dog strengthens his awareness of the beauty of both animate and inanimate objects, by the end of the novel the cantankerous Ray grasps an aesthetic vision of life, declaring that "everything holds a diaphanous kind of potential." (Baume 2015: 277) 


\section{ANIMAL AND HUMAN BODIES}

In a recent essay by Kathryn Kirkpatrick (2015), it is suggested that animals have always been an essential part of Irish writing: not only as added plot elements but on a symbolical level as representations of Irishness. The evocation of the animal in literature can symbolically expand the understanding of concepts like race, ethnicity, gender, class. As Kirkpatrick points out, the Irish have often been compared to animals, which was "justified by the colonial use of force to subdue and constrain." (2015: 1) One of the earliest literary accounts on the Irish was given by a half-Norman half-Welsh priest, Gerald of Wales, in The History and Topography of Ireland (1185). His perspective is driven by the dominating force of the colonizer, denoting that Irish people are "wild and inhospitable people. They live on beasts only and live like beasts." (Gerald of Wales 1185: 101) Kirkpatrick suggests that the "representations of the animals have literal consequences for nonhuman animal lives," (2015: 3) creating a subordinated, degraded category of animality. She urges the need for a new methodology and means of understanding that can be initiated by literature:

If, as scientists maintain, we are now living in the Anthropocene era, then clearly reframing of life on earth has produced the awareness that humans must better understand the other creatures with which they share the planet in order to come to grips with the fouling of both human and nonhuman habitats. (Kirkpatrick 2015: 2)

Literary representations of animals can shape the way us humans relate to these creatures. According to Kirkpatrick (2015: 3), literary texts often portray animal species as being subordinates to humans, creating a degrading effect. Sara Baume's novel seeks to dismantle old, traditional representations of the human-animal relationship. The narrative's experimental power lies not only in its language but also in its thematic innovations. The addressee of the text is the one-eyed dog, "I address it all to you. You who never spoke anyway. You who misunderstands everything." (Baume 2015: 163)

The human and animal body is a major element of focus in the novel. Baume chooses a character who lacks the ability to use the full communicative potential of language, who lives a lonely, resigned life. At the same time, Ray manages to arrive at a deep understanding of the natural world through his senses. This suggests that the animal-type is a more authentic form of communication. The mode of living that occurs in the natural world compared to the thought-driven, sometimes 'overthought' societal mode of humans is given a primordial role here in this novel. This is further sustained by the chosen narrative structure signaled in the title, denoting the rhythm of the four seasons. The seasonal changing of the landscape is concurrent with the moral, emotional changes occurring in the character's life. Ray slowly transforms from an old cantankerous, lonely man to a vulnerable, forgiving, kind member of the community. The pace of existence is slowed down in this novel, undertaking the slow movements of the inanimate world. However, at the same time, there is also a constant experience of motion. Even the transformed season-names become verbs that denote physical action: spill, simmer, falter and wither. 
The reader sees the dog constantly running, roaming through the landscape, and this movement becomes a stylistic device. It can be compared to a cinematic technique where the protagonist is the camera that functions as a projector of the setting, without any judgmental diction. The motion of nature is there, captured through descriptive language, but there is no real human action. The whole plot operates within this device, adequately grasped by Ray at the end of the novel: "I close my eyes, and our life is a film, and we are rolling, rolling, rolling." (Baume 2015:276) This way, the focus of the narrative is expanded, creating a third nonhuman character in the plot, that being nature itself. As Ray learns to cope with silence, paradoxically, he gives voice to the natural world, through his monologic utterances. Baume herself admits that the novel is "very much about nature too; the setting is very important." (Crim 2016) It can be suggested that through her innovative prose style, she anthropomorphizes the nonhuman world into a body: a felt, throbbing physicality. This strategy may lie open the charge of pathetic fallacy. The term itself denotes the process through which humans present the natural world around them in terms of their own personal feelings. This leads to the conclusion that whatever is visualized and described by language is processed and modified by the viewer's internal emotional bias. Baume's prose may lie open to the charge of pathetic fallacy, yet in her case, it cannot be considered a falsification. Even if the landscape is transmitted through a distorting subjective mood, the process itself is authentic. The narrative carries the readers into the process through which the character experiences the natural environment. It shapes a new vision of the attempt to apprehend our natural habitat and the world of animals in a reverential way. At the same time, it opens up the human body as a closed system of organs working together while at the same time directing its sensory receptacles out into the natural world. The process of symbiotic pathos-generation rather than the outcome as putatively a pathetic fallacy is what is important here. This is still a process through which, as Elaine Scarry (1985) argues, humans relieve themselves of their own pain and suffering.

The novel can also be termed a geographic, almost scientific itinerary through the wild rural landscapes of Ireland. Ray knows all the elements of nature, from plants to trees and rocks. By the end of the novel, he almost gains a superhuman ability to sense, smell, view these as acutely as his hunter dog. He embodies the dog through an almost intimate connection, trying to feel the world as the animal to an almost anatomical degree:

You shift your weight to lean against my shin. You're dry and warm and soft yet solid. I feel the bulge and fall of your ribcage as you sigh. I find it strange because I always thought of sigh as an expression of the sort of feeling which animals are not supposed to be capable of, and I wonder do you sigh because you have the smog inside you, my sapping smog. Does it build within your chest until your muscles spasm and push it out, away. (Baume 2015: 75)

There is a constant dynamic of human-animal perception in this novel. The adjectives point to the tactile sensations that Ray experiences as "dry, warm, soft" yet the proprioceptive description of the sigh is an assigned: a human sensation that he envisions as felt by the dog. Baume's narrative is experimental in this explorative 
manner of using the narrative language with expressive power. This mode comes very close to that suggested by Kirkpatrick (2015), one that can reshape the imbalance of the human-animal ontology. It can reiterate the "anthropocentric existence" by using degraded outcast characters from both worlds, who yet achieve the deepest mutual understanding. Baume herself stated that the intention was to "give voice to the overlooked guy, the strange guy on the street who doesn't stand for anything visual or tangible, but has a soul as well." (Crim 2016: par. 14) One-Eye similarly is the least appealing creature, yet through the eyes of Ray, he is viewed as an equal, without a discombobulated sense of its "0therness." There is a crucial moment in the narrative where this equity liberation is carried to a heightened persuasive level. On their adventurous journey, Ray notices a family stopped at the side of a road, with a woman crying while staring at something. As Ray comes closer, he notices that the scene is prompted by a dead body of a swan. This reminds him of all the other dead animals that they encountered on the roadsides:

Now we see it, lying in the middle of the road. A swan, a mute swan [...] We see its wings are tucked back as if the tar is liquid and the swan is swimming. [...] The woman is kneeling down besides the swan. I think she is crying. [...] I think of all the creatures we've seen since we set out. [...] Why didn't anyone stop for the jackdaw? Because the swan looks like a wedding dress that's why. Whereas the jackdaw looks like a bin bag. Because this is how people measure life. (Baume 2015: 148-149)

As critic Torrey Crim suggests, this is a pivotal scene that strengthens the strong argument against anthropocentrism, showing the unfair treatment of "how we value animal life versus human life." (Crim 2016) It also resonates with the argument posed by Derrida in his work, The Animal That Therefore I am (2008), where he states that the human-nonhuman binary has been for too long based upon false assumptions. The animal-human opposition has been characterized by a deceptive recognition of failure that needs to be re-addressed. While one cannot escape the human experience through which we unfairly project ourselves into animals, we can change the way we think about them. Instead of defining it in the same methodological context, we should accord a distinct mode of existence to them that is not constrained by human attributes. As Derrida sustains, it is less a matter of asking: "whether what calls itself human has the right rigorously to attribute to man [...] what he refuses the animal." (2008: xi)

\section{NEW MODES OF COEXISTENCE}

Sara Baume's novel is a living experiment. Innovative in many ways and at the same time using the ancient capacity of language to carry and express intimate human, body-tied experiences like fear, love and ageing. Ray offers a possible, new means of co-existence with the natural world and also with our own limited body. His fear of death that features strongly at the beginning of the narrative transforms into a zest for life. He learns to appreciate the world he lives in and discovers a new humility towards the natural world. The connection he has with his dog is one that does not involve 
inequality, degradation or dominion. It can be suggested that in our Anthropocene era, this is an important path that we need to discover because in it lays our collaborative survival. Only through a deep reverence for the natural world can a viable future be built. One is reminded here of anthropologist's, Anna Lowenhaupt Tsing's account of the matsutake mushroom in The Mushroom at the End of the World (2015). It is a species that grows in Europe, Northeast Asia, and the Pacific Northwest but interestingly only in human-disturbed forests. This mushroom becomes thus a metaphor of a new type of humanity, one that is serendipitously interconnected to other species and the natural world. Baume, in her novel Spill Simmer Falter Wither (2015) via her character Ray, also imagines a similar future, urging us to re-construct our relation to the world and our own complex bodies.

\section{REFERENCES}

Baume, S. 2015. Spill, Simmer, Falter, Wither. London: Windmill.

Baume, S. 2015. The Ormonde. International Writing Program Archive of Residents Work. 906. [Internet]. Available at: http://ir.uiowa.edu/iwp_archive/906 [24. 4. 2020].

Clark, A. 2017. Sara Baume: 'I always wanted to be an art monster.' The Guardian. 18 February. [Internet]. Available at: https://www.theguardian.com/books/2017/ feb/18/sara-baume-interview-a-line-made-by-walking [24. 4. 2020].

Crim, T. 2016. In conversation with Sara Baume. The Brooklyn Rail, 11 July. [Internet]. Available at: https://brooklynrail.org/2016/07/books/sara-baume-with-torreycrim [22. 4.2020].

Davey, M. E. 2010. 'She had to start thinking like a man': Women Writing Bodies in Contemporary Northern Irish Fiction. Estudios Irlandeses 5, 1-24. [Internet]. Available at: http://www.estudiosirlandeses.org/wp-content/uploads/2013/05/ Maeve_E_Davey.pdf [20.3. 2020].

Dass, K. 2019. Author Sinéad Gleeson: Writing you story is a way to control your narrative. NZ Herald, 2 November. [Internet]. Available at: https://www.nzherald. co.nz/lifestyle/news/article.cfm?c_id=6\&objectid=12281683 [20.4. 2020].

Derrida, J. 2008. The Animal That Therefore I Am (trans. D. Wills). New York: Fordham UP.

Enright, A. 2019. Reviewing Sinéad Gleeson's book, Constellations. [Internet]. Available at: http://www.sineadgleeson.com [20. 4.2020].

Gerald of Wales. 1185 [1982]. The History and Topography of Ireland (trans. J. 0'Meara). Harmondsworth: Penguin Books.

Gleeson, S. 2019. Constellations. London: Picador.

Herman, D. 2010. Narrative Theory after the Second Cognitive Revolution. In L. Zunshine (ed.) Introduction to Cognitive Cultural Studies. Baltimore: The John Hopkins UP, 155-175.

Hillman, D. and U. Maude. 2015. Introduction. In D. Hillman and U. Maude (eds.) The Cambridge Companion to the Body in Literature. Cambridge: Cambridge UP, 1-9.

Kirkpatrick, K. 2015. Introduction. In Kirkpatrick, K. and B. Faragó (eds.) Animals in Irish Literature and Culture. Hampshire: Palgrave Studies, 1-10. 
Kolk, van der B. 2015. The Body Keeps the Score: Mind, Brain and Body in the Transformation of Trauma. London: Penguin Books.

Mahon, Á. 2017. Moral Education and Literature: On Cora Diamond and Eimear McBride. Journal of Philosophy of Education 51(1), 102-113.

Merleau-Ponty, M. 2004. The World of Perception (trans. 0. Davis). New York: Routledge. Nancy, J. L. 2008. Corpus (trans. R. A. Rand). New York: Fordham UP.

Rabaté, J.M. 2015. Literature and Affect. In D. Hillman and U. Maude (eds.) The Cambridge Companion to the Body in Literature. Cambridge: Cambridge UP, 230-245.

Ryle, G. 2009. The Concept of the Mind. New York: Routledge.

Scarry, E. 1985. The Body in Pain: The Making and Unmaking of the World. Oxford: Oxford UP.

Tsing Lowenhaupt, A. 2015. The Mushroom at the End of the World. Princeton: Princeton UP.

\section{SUMMARY}

\section{COLLABORATIVE COEXISTENCE: HUMAN-ANIMAL BODIES AND NATURE IN SARA BAUME'S SPILL, SIMMER, FALTER, WITHER}

The following paper focuses on contemporary Sara Baume's, Irish novelist's debut novel, Spill, Simmer, Falter, Wither (2015). It examines how Baume's uses language to create an experimental narrative that doesn't revolve around a fast-moving and dramatic plot yet forces the reader into the middle of the experience. Her meticulously descriptive language allows the reader to become closely tied to the experiencing body and see the landscape, the animal world, and the visceral means that it delivers to the body. The essay also analyses the innovative ways through which the novel reexamines the animal-human bond, urging a newly imagined co-existence in our current Anthropocene era. Baume touches upon crucial ethical topics and raises important questions about the possibility of a more harmonious bond between humans and the natural world.

KEYWORDS: contemporary Irish fiction, body, animal, landscape, language, Anthropocene, narrative.

ARTICLE INFO:

Original research article

Received: May 5, 2020

Revised: June 8, 2020

Accepted: June 30, 2020 